DOI https://doi.org/10.30525/978-9934-26-074-2-40

\title{
АДМІНІСТРАТИВНО-ПРАВОВЕ РЕГУЛЮВАННЯ ДЕРЖАВНОГО ФІНАНСУВАННЯ НАУКИ: НАЦІОНАЛЬНИЙ ФОНД ДОСЛІДЖЕНЬ УКРАЇНИ
}

\author{
Халілова А. Г. \\ аспірантка кафедри адміністративного права \\ Національного юридичного університету імені Ярослава Мудрого \\ м. Харків, Україна
}

Держава, по відношенню до науки, виступає: 1) як законодавець, який встановлює нормативно - правові засади функціонування суспільства в цілому, в тому числі його науково-технічного сегмента; 2) як один 3 головних джерел фінансування наукових досліджень, розробок та інновацій; 3) як найбільший суб'єкт науково-технічної діяльності; 4) як великий замовник і споживач нової технічної продукції, в тому числі одиничної і унікальною; 5) як політична сила, здатна значною мірою визначити ставлення всього суспільства до проблем розвитку науки $\mathrm{i}$ техніки. Державне фінансування науки $є$ одним 3 основних інструментів управління, який широко використовується у всіх країнах світу. Належний стан фінансування наукової діяльності $є$ найважливішим аспектом розвитку науки.

Конституція України у статті 54 встановлюе, що держава сприяє розвиткові науки, встановленню наукових зв'язків України зі світовим співтовариством [1]. Відповідно до змісту статті 48 Закону України «Про наукову i науково-технічну діяльність» одним із основних інструментів реалізації державної політики у сфері наукової і науковотехнічної діяльності є бюджетне фінансування, яке здійснюється за рахунок коштів державного бюджету [2].

У розвинених країнах світу важливу роль в стимулюванні науки відіграють державні фонди підтримки наукової діяльності. В Україні такий фонд був створений у 1992 році, головним завданням Державного фонду фундаментальних досліджень була організація та підтримка на конкурсній основі фундаментальних наукових досліджень. Середньостроковий план пріоритетних дій Уряду до 2020 року, затверджений розпорядженням Кабінету Міністрів України від 3 квітня 2017 р. № 275-р, встановив, що розв'язання проблеми утворення фінансуючої установи 3 широкими міжвідомчими можливостями можливе шляхом утворення Національного фонду досліджень, що передбачено Законом України «Про наукову і науково-технічну діяльність». У зв’язку зі 
створенням Національного фонду досліджень України Міністерством освіти інауки України видано наказ від 28.01.2019 № 79 «Про реорганізацію Державного фонду фундаментальних досліджень». Відповідно до нього Державний фонд фундаментальних досліджень припинив своє існування, шляхом приєднання до Національного фонду досліджень, який $є$ його правонаступником.

Кабінет Міністрів України утворює Національний фонд досліджень України 3 метою стимулювання фундаментальних та прикладних наукових досліджень, реалізації єдиної державної політики у сфері наукової та науково-технічної діяльності в межах його повноважень, розвитку національного дослідницького простору та його інтеграції до світового дослідницького простору, розбудови дослідницької інфраструктури в Україні та іiі інтеграції до світової дослідницької інфраструктури.

Згідно із Положенням про Національний фонд досліджень України [3], це державна бюджетна установа. Функції з управління Національним фондом виконує Кабінет Міністрів України. Фонд є головним розпорядником бюджетних коштів, і розмір бюджетного фінансування Фонду визначатиметься на підставі пропозицій Національної ради 3 питань науки i технологій. Кошти Фонду можуть формуватися за рахунок державного бюджету, добровільних внесків юридичних і фізичних осіб, тобто донорів, у тому числі нерезидентів України, а також 3 інших джерел, не заборонених чинним законодавством.

Основним завданням Національного фонду досліджень України $\epsilon$ грантова підтримка: 1) фундаментальних наукових досліджень у галузі природничих, технічних, суспільних та гуманітарних наук; 2) прикладних наукових досліджень i науково-технічних (експериментальних) розробок за пріоритетними напрямами розвитку науки i техніки. Фонд діє відповідно до принципів максимальної відкритості та прозорості, незалежності та об'єктивності наукової і науково-технічної експертизи проектів, поваги й дотримання авторських прав, принципів наукової етики, засад доброчесної конкуренції.

Органами управління Національного фонду досліджень є Наглядова рада, Наукова рада, Голова Фонду, Дирекція Фонду. Функції наглядової ради Фонду виконують 24 члени Наукового комітету Національної ради 3 питань розвитку науки і технологій, які координують і контролюють діяльність Фонду. Наукова рада складається з 30 провідних вчених та науковців, яких обрала Наглядова рада через Ідентифікаційний комітет. Наукова рада поділяється на три секції: секцію природничих, технічних наук і математики (14 осіб); секцію біології, медицини та аграрних наук (9 осіб); секцію соціальних та гуманітарних наук (7 осіб). Голова Фонду 
обирається зі складу наукової ради Фонду, призначається на посаду строком на три роки, не більш як два строки, після завершення строку повноважень, він не може бути членом наукової ради Фонду. Дирекція $\epsilon$ виконавчим органом Фонду, яка складається 360 осіб -штатні співробітники Фонду, які допомагатимуть членам i Наукової ради, i Наглядової ради, оскільки вони працюють на громадських засадах.

Організаційною формою роботи наукової ради Фонду є засідання, які скликаються і проводяться головою наукової ради Фонду, засідання проводяться у разі потреби, але не рідше одного разу на три місяці.

На нашу думку, Національний фонд досліджень є одним з ключових елементів реформи системи фінансування науки України, адже ідея створення та діяльності такого фонду, як інструменту прямого бюджетного фінансування наукової діяльності наближена до світової системи бюджетування, яке орієнтоване на результат (БОР). Впровадження схеми БОР відповідає двом цілям: по-перше, покращення механізму управління науковими дослідженнями шляхом підвищення його прозорості; подруге, стимулювання конкуренції між суб'єктами наукової діяльності [4, с. 18]. Отже, ідея виділення фінансових коштів на наукові дослідження на конкурсній основі сприяє інтеграції України до європейського наукового простору, що $є$ одним із ключових пріоритетів зовнішньої політики держави.

Яскравим прикладом успішного існування подібних фондів в європейських країнах, може слугувати фонд Німецьке науково-дослідницьке співтовариство (нім. Deutsche Forschungsgemeinschaft) - головна самоврядна суспільна установа по сприянню науковим дослідженням у ФРН [5]. За своїм статусом це фонд, що фінансується переважно 3 державного бюджету. Його завданням $\epsilon$ перш за все фінансова підтримка науково-дослідних проектів в вузах і державних науководослідних установах, відбір проектів здійснюється на конкурсній основі.

Як згадувалося вище, німецький фонд $є$ самоврядною установою, у зв'язку з чим, піднімалися питання, чи відповідає організаційно-правова форма фонду умовам його діяльності. Критиці піддавалися два основних аспекти: нерозкриття причин відхилення заявок і неможливість подати апеляцію в разі відхилення. Так, один із заявників, що отримав відмову в результаті експертизи, вимагав через суд надання йому експертного висновку за його проектом в письмовій формі. Він обгрунтував свою вимогу тим, що бажає використовувати зауваження експерта для вдосконалення майбутніх проектів. При цьому заявник посилався на те, що Німецьке науково-дослідницьке співтовариство є організацією, на яку розподіляються бюджетні кошти, отже, на неї поширюється вимога прозорості діяльності. Позов не був задоволений з посиланням на те, що 
фонд є не державною установою, а приватною організацією, на яку, на відміну від державних установ, не поширює дію Закон про свободу інформації ФРН. Після такого інциденту з'явилося нове визначення Німецького науково-дослідницького співтовариство як «типової напівдержавної організації», у цьому випадку вона повинна відповідати вимогам прозорості [6, с. 202].

Отже, функціонування такого інституту, як Національний фонд досліджень має позитивно вплинути на становлення конкурентоздатного рівня української науки. Без сумніву такий інструмент підтримки наукової та науково-технічної діяльності потребує подальшого вдосконалення. Не тільки в частині збільшення обсягів фінансування наукових досліджень, а й поряд 3 цим у частині розроблення системи заходів, спрямованих на підвищення відповідальності органів виконавчої влади, академій наук та фондів підтримки наукової діяльності за цільове та ефективне витрачання бюджетних коштів.

\section{Література:}

1. Конституція України: Закон України від 28.06.1996 № 254к/96-ВР. Голос України, від 13.07.1996, № 128. URL: https://zakon.rada.gov.ua/ laws/show/254к/96-вр\#Text

2. Про наукову i науково-технічну діяльність: Закон України від 26.11.2015 № 848-VIII. Відомості Верховної Ради, 2016. № 3 URL: https://zakon.rada.gov.ua/laws/show/848-19

3. Положення про Про Національний фонд досліджень України: Постанова Кабінету Міністрів України від 04.07.2018 № 528. Урядовий кур ` $є р, 10.07 .2018$, № 126. URL: https://zakon.rada.gov.ua/laws/ show/528-2018-п\#Text

4. Jonkers K. et al. Research Performance Based Funding Systems: a Comparative Assessment. Institute for Prospective Technological Studies, Joint Research Centre. 2016. № JRC101043

5. Deutsche Forschungsgemeinschaft : Mission Statement: офіційний сайт. URL: https://www.dfg.de/en/dfg_profile/mission/index.html

6. Водяницкая Е.А. Роль и место Немецкого научно-иследовательского сообщества в научной политики ФРГ. Вестник МГИМОУниверситета. 2013. С. 197-205. 